\title{
HUBUNGAN FAKTOR PREDISPOSING, ENABLING DAN REINFORCINGDENGAN PERILAKU SEKSUAL PRANIKAH PADA REMAJA SMA
}

\author{
Harry Sundoro \\ Universitas Islam Sumatera Utara, JI. STM, No. 77 Medan. \\ Email: dr.harrysundoro@yahoo.com
}

\begin{abstract}
Deviant sexual behavior among unmarried adolescents in terms of reproductive health tends to increase. Premarital sexual behavior in adolescents in high school. The phenomenon of sexual behavior among adolescents according to The Board of Coordinator for National Family Planning in the field as much as 52\% had premarital sex. The objective of the research was to find out the correlation of predisposing factors, Enabling and Reinforcing the Pre-Marital Sexual Behavior in Adolescents XY high school in the city of Medan. The research used explanatory method and cross sectional study design. The data were gathered by conducting interviews and questionnaires and analyzed by using multiple logistic regression analysis at a $=0.05$. The result of this study showed pre-marital sexual behavior $52.4 \%$ of high-risk category. Predisposing factors, $64.5 \%$ category is not good knowledge, the attitude of $57.3 \%$ in the negative category, socioeconomic $54.0 \%$ in the low category. Enabling factors; $54.8 \%$ of media access information on exposure category, $58.1 \%$ availability of the facilities available in the category. Reinforcing factors; $58.1 \%$ of parents have role category, $53.2 \%$ of peers have no role category. The result of statistic test showed that predisposing factors (knowledge, attitudes, social and economic) and enabling factors (media access to information and the availability of facilities) as well as reinforcing factors (the role of parents and the role of peers) were correlated $(p<0.05)$ with the pre sexual behavior marriage. The variable of knowledge had the most dominant correlation with the pre sexual behavior marriage.
\end{abstract}

Keywords: Predisposing factors, Enabling, Reinforcing, Teenagers

\section{PENDAhuluan}

Perilakuseksual

yang

menyimpangdikalanganremajabelummenikahce nderungmeningkat.Beberapapenyebab yang mempengaruhipenyimpanganperilakuseksualad alah akibat dari perkembanganarusglobalisasi, teknologidaninformasisertafaktorlainnya, sehinggamempengaruhiperubahanperilakuseks ualkehidupanremaja.Penyimpanganperilakusek sualdapat berupa penyimpangan perilakukesehatanreproduksi. penyimpangan perilaku memerlukanperhatiandanpenangananagar merekatidak beresiko terkena gangguan perilaku maupun gangguan kesehatansepertiperilakuseksualpranikah, Napza, HIV/AIDS, danAborsi (BKKBN 2011).

Survei Durex dan Harris Interactive padatahun 2007, menunjukkanbahwausia rata-rata kehilangankeperawan di Indonesia sekitar 19,1tahun. Angkaini berada di urutanke 9 dari Negara Asia, yaitu Malaysia (23 tahun), India (22,9tahun), Singapore (22,8 tahun), China (22,1 tahun), Thailand (20,5 tahun), Hongkong 


\begin{tabular}{l|c|c}
\hline JURNALPENELITIAN KESMASY & VOL. 1 NO. 2 & $\begin{array}{c}\text { EDITION: NOVEMBER 2018 - } \\
\text { APRIL2019 }\end{array}$ \\
\hline & http://ejournal.delihusada.ac.id/index.php/JPKSY & \\
\cline { 2 - 3 } RECEIVED: 6 JANUARI 2019 & REVISED: 8 MARET 2019 & ACCEPTED: 15 MARET 2019 \\
\hline
\end{tabular}

(20,2 tahun), Vietnam (19,2 tahun), Jepang (19,4 tahun), dan Taiwan (18,9 tahun). Namun, angkaini masih di atasusia rata-rata di 27 negaraEropayaitusekitar 16 tahun, denganusiatertinggi di Spanyolsekitar 19,2 tahundanusiaterendah Iceland yang sekitar 15,6 tahun, maupunjuga di AmerikaSerikatsekitar 18 tahun (KesehatanKompasiana, 2010).

Menurut

BKKBN mencatatproyeksipenduduk Indonesia tahun 2000-2025 padatahun 2007 jumlahremajaumur 10-24 tahunsekitar 64 jutaatau $28,6 \%$ darijumlahpenduduk Indonesia sebanyak 222 juta. Jumlahremaja

yang terusmeningkatdapatterjadipermasalahankomp leksseiringdenganmasatransisidanmasalah

yang terjadidalamkehidupanremaja yang rentandenganrisikokesehatanreproduksiremaja seperti penyakit seksual, Napza, HIV dan AIDS.Hasilkajian BKKBN tahun 2010, menyimpulkanbahwa di wilayahJabodetabek rata-rata dari 100 remaja, sekitar 51\% pernahmelakukanhubunganseksualpranikahdan di Surabaya mencapai 54\%, Bandung 47\%, Yogyakarta 37\% serta Kota Medan 52\%.

MenurutKementerianKesehatan

(2011)

penderita

AIDS

sebagianbesarterjadipadakelompokremaja.Kas

us HIV di Indonesia tahun 1987 sampaidengan

2011 sebanyak 76.879 kasus, sedangkanpenderita AIDS berjumlah 29.879 kasusdimana

5.430

diantaranyamengalamikematian. KasusHIV dapat terjadipadakelompokumur 20-24 tahunada sebanyak 3.113 kasus atau sebesar $14,8 \%$ dari total kasusdanpadakelompokumur 15-19 tahunterjadi sebanyak 683 kasus atau sebanyak 3,2\% pada tahun 2011. Proporsikumulatifpenderita AIDS hingga tahun 2011 adalah yangtertinggidilaporkanpadakelompokumur 2029 tahun yaitu45, $9 \%$. Sedangkanjumlahpenderita AIDS padakelompokumur 15-19 tahunada sebanyak $3,4 \%$. Hal inimenggambarkansebagianbesarpenderita AIDS mulaipadamasaremaja yang membutuhkanwaktubeberapatahunkemudian, sehinggadiketahuimenjadipenderita AIDS.

Hasillaporan tahun 2008 yang dirilis oleh LembagaStudiCintadanKemanusiaansertaPusat PenelitianBisnisdanHumaniora (LSCK-PUSBIH), menunjukkan bahwadari $\quad 1.660$ respondenmahasiswi di Yogyakarta atau sekitar 97,05\% mengakusudahkehilangankegadisannyadan 98 orang diantaranya mengakupernahaborsi. Hal ini senada dengan apa yang telah dirilis PKBI tahun 2006 yang menyatakan: kisaranumurpertamakali

melakukanhubunganseksual adalah 13-18 tahun, sebanyak $60 \%$ diantaranya tidakmenggunakanalatatauobatkontrasepsi, dan berkenaan dengan lokasi menunjukkan bahwa sebanyak $85 \%$ dilakukan di rumahsendiri.

HasilsurveiAsfriyati

(2005)tentangperilakuseksualpranikahpadarem aja di Kota Medan menunjukkan bahwa sekitar 5,5-11\% remajasebelumusia 19 tahun telah melakukan hubungan seksual, dan 14,7-30\% remaja yang kuliah (mahasiswa) padausia 1524 tahunsudahmelakukanhubunganseksual.

Masaremajamerupakanperiodetransisiantarama saanak-anakdanmasadewasa yang diwarnaiolehpertumbuhan, perubahan, munculberbagaikesempatandanseringkalimeng hadapirisiko-risikokesehatanreproduksi (Azinar, 2013).Remajapertama kali pacaranpadausia 12 tahun. Berkenaan dengan perilakupacaranremajajugasemakinpermisifyak nisebanyak $\quad 92 \%$ remajaberpegangantangansaatpacaran, $82 \%$ berciuman, 63\% rabaan petting (KPAI, 2012).

MenurutSarwono(2012) perilakuseksualyang didorongolehhasratseksual ditunjukkan oleh tingkahlakuseksualyang dimulai dariperasaantertarik, berkencan, bercumbu, danbersenggama, sehinggamelakukanhubunganseksualpranikah. SedangkanmenurutSurveiKesehatanReproduksi Remaja Indonesia (SKRRI) tahun 2003, faktor yang

mempengaruhiremajamelakukanhubunganseks 


\begin{tabular}{l|r}
\hline \multicolumn{1}{c|}{ JURNALPENELITIAN KESMASY } & \\
\hline \multicolumn{1}{c|}{ RECEIVED: 6 JANUARI 2019} & http://ejournal.delihusad \\
\cline { 2 - 2 } $\begin{array}{l}\text { ualpranikahadalah } \\
\text { pengaruhtemansebaya,adanya } \\
\text { dapat } \\
\text { berhubungansekspranikahdanadanya } \\
\text { temanyang } \\
\text { mendorongmelakukansekspranikah. }\end{array}$ & $\begin{array}{r}\text { Remat } \\
\text { temyang } \\
\text { diajak }\end{array}$ \\
\end{tabular}

Sekolahmerupakanlingkungansekunderbagirem ajasetelahlingkungankeluarga.Sekolah memiliki peran dalam membentuk perilaku remaja, seperti membantu memberikan penjelasan tentang seks pra nikah dan kesehatan reproduksi dengan baik dan benar. Berdasarkan survei pendahuluan pada bulan Oktober 2014 di dua SMA di Kota Medan diketahui bahwa SMA pertama memiliki siswa berjumlah 644 orang, terdiri dari 268 orang laki-laki $(41,6 \%)$ dan 376 orang perempuan $(58,4 \%)$. Sedangkan SMA kedua memiliki siswa berjumlah 174 orang, terdiri dari 31 orang laki-laki $(17,8 \%)$ dan 143 orang perempuan $(82,2 \%)$.

Kedua SMA tersebut letaknya dekat dengan daerah perkotaan, strategis dengan pusat perbelanjaan (keramaian), sehingga situasi ini memberi peluang bagi remaja ini untuk mengakses informasi baik melalui media massa, cetak, VCD, buku, dan film porno, maupun elektronik dan didukung dengan kelengkapan fasilitas internet serta fasilitas yang mendukung perilaku berisiko terhadap perilaku seksual pra nikah. Beberapa masalah di kedua sekolah ini adalah; siswa kerap terlambat datang ke sekolah, sering bolos, ketidakhadiran mengikuti pelajaran dengan alasan absen.

Hasilwawancaraterhadap

guru bimbingandankonselingpadakeduasekolahterse but, ditemukanterjadipeningkatanperilakuseksualpr anikahdimanapadatahun 2013 tercatatsebanyak 5 orang (dari kedua sekolah) dantahun 2014 tercatatsebanyak 7 orang (dari kedua sekolah)masingmasingmeningkatsebesar $\quad 0,3 \% \quad$ yang mengakibatkanremajahamil di luarnikah, salahsatupenyebabhaliniterjadiadalahpengetah uanremaja yang rendahtentangkesehatanreproduksidandiikutim asyarakatperkotaan yang cenderungpermisif, mudahmengaksesinformasimelalui media internet sertakurangnyapengawasan.

Oleh karena itu, penelitian ini bertujuan untuk: menganalisis hubungan faktor predisposing (pengetahuan, sikap dan sosial ekonomi), enabling (akses media informasi, ketersediaan fasilitas) dan reinforcing (peran orang tua dan teman sebaya)dengan perilaku seksual pra nikah pada remaja SMA di Kota Medan.

\section{METODE PENELITIAN}

Penelitian ini merupakan penelitian kuantitatif dengan rancangan penelitian Cross-Sectional Study, yaitu penelitian yang sifatnya sesaat pada suatu waktu tertentu dan dalam kurun waktu tertentu dan menjawab gejala dalam kurun waktu tertentu. Jenis penelitian ini merupakan penelitian survei dengan pendekatan explanatory

Penelitian ini dilakukan di SMA Kartika 1-2 Medandan SMA Almanar Medan dengan pertimbangan adanya penyimpangan perilaku seksual pra nikah yang mengakibatkan remaja hamil di luar nikah. Populasi dalam penelitian ini seluruh remaja SMA yang berusia 15-18 tahun di kedua SMA tersebut berjumlah 560 orang terdiri dari laki-laki 205 orang dan perempuan 355 orang.

Data primer diperoleh melalui wawancara langsung dengan responden dan data sekunder diperoleh dari dokumen registrasi siswa di kedua SMA tersebut. Data dianalisis menggunakan uji regresi logistik berganda pada taraf kepercayaan $95 \%$.

\section{HASILPENELITIAN}

Hasil penelitian menunjukkan bahwa remaja sebagai responden lebih banyak duduk di kelas XI, yaitu sebanyak 73 orang (58,9\%) dengan kelompok umur 15-17 tahun, pada penelitian ini ditemukan lebih banyak remaja dengan kelompok umur 16 tahun, yaitu sebanyak 69 orang $(55,6 \%)$.

Peran gender merupakan bagian dari peran sosial dan jenis kelamin bukan sebagai faktor pennentu peran sosial namun dipengaruhi oleh faktor lingkungan dan faktor-faktor lainnya 


\begin{tabular}{l|c|c}
\hline JURNALPENELITIAN KESMASY & VOL. 1 NO. 2 & $\begin{array}{c}\text { EDITION: NOVEMBER 2018 - } \\
\text { APRIL2019 }\end{array}$ \\
\hline & http://ejournal.delihusada.ac.id/index.php/JPKSY & \\
\cline { 2 - 3 } RECEIVED: 6 JANUARI 2019 & REVISED: 8 MARET 2019 & ACCEPTED: 15 MARET 2019 \\
\hline
\end{tabular}

(Sarwono, 2011). Berdasarkan jenis kelamin sebagian besar perempuan, yaitu sebanyak 78 orang $(62,9 \%)$ dan sebagian besar tinggal bersama orang tua, yaitu sebanyak 71 orang $(57,3 \%)$.

sebanyak 80 orang $(64,5 \%)$ memiliki pengetahuan yang berada pada kategori tidak baik. Jawaban responden tentang pengetahuan belum sepenuhnya sesuai dengan semestinya. Hasil uji bivariat ada hubungan pengetahuan dengan perilaku seksual pranikah dan secara multivariat pengetahuan remaja berhubungan positif dan signifikan dengan perilaku seksual pranikah (RP; 10,696; 95\% CI=1,832-62,450).

Sebanyak 71 orang $(57,3 \%)$ memiliki sikap dengan kategori negatif terhadap seksualitas. Responden menyikapi perilaku seks pra nikah cenderung ke arah permisif. Hasil uji bivariat menunjukkan ada hubungan sikap dengan perilaku seksual pranikah dan secara multivariat sikap remaja berhubungan positif dan signifikan dengan perilaku seksual pranikah (RP; 5,076; 95\% CI=1,217-21,172).

Hasil penelitian menunjukkan sosial ekonomi pada kategori rendah sebanyak 67 orang (54,0\%). Hal ini memberikan gambaran bahwa sebagian besar orang tua anak remaja memiliki sosial ekonomi yang belum baik. Hasil uji bivariat menunjukkan ada hubungan sosial ekonomi dengan perilaku seksual pranikah dan secara multivariat sosial ekonomi berhubungan positif dan signifikan dengan perilaku seksual pranikah (RP; 6,376; 95\% CI=1,418-28,672).

Hasil penelitian juga menunjukkan bahwa akses media informasi sebanyak 68 orang $(54,8 \%)$ pada kategori terpapar. Hal ini memberikan gambaran bahwa sebagian besar responden terpapar karena adanya media informasi. Hasil uji statistik bivariat mengindikasikan ada hubungan akses media informasi dengan perilaku seksual pranikah dan secara multivariat akses media informasi berhubungan positif dan signifikan dengan perilaku seksual pranikah (RP; 4,577; 95\% $\mathrm{CI}=1,142-18,343)$.
Terkait ketersediaan fasilitas yang mendukung perilaku berisiko, sebanyak 72 orang $(58,1 \%)$ menyatakan bahwa dilingkungannya tersedia. Hasil uji statistik secara bivariat menunjukkan ada hubungan ketersediaan fasilitas yang mendukung perilaku berisiko dengan perilaku seksual pranikah dan secara multivariat ketersediaan fasilitas yang mendukung perilaku berisiko berhubungan positif dan signifikan dengan perilaku seksual pranikah (RP; 5,116; 95\% CI=1,264-20,696).

Sebanyak 72 orang orang tua $(58,1 \%)$ pada kategori berperan dalam pendidikan seksual. Hasil uji statistik secara bivariat menunjukkan ada hubungan peran orang tua dengan perilaku seksual pranikah dan secara multivariat peran orang tua berhubungan positif dan signifikan dengan perilaku seksual pranikah (RP; 5,616; 95\% CI=1,056-29,858).

Ada sebanyak 63 orang teman sebaya $(50,8 \%)$ pada kategori tidak berperan. Hasil uji statistik secara bivariat menunjukkan ada hubungan peran teman sebaya dengan perilaku seksual pranikah dan secara multivariat peran teman sebaya berhubungan positif dan signifikan dengan perilaku seksual pranikah (RP; 7,401; $95 \% \mathrm{CI}=1,436-38,140)$.

\section{PEMBahasan}

\subsection{Hubungan Pengetahuan dengan Perilaku Seksual Pra Nikah}

Jawaban responden tentang pengetahuan belum sepenuhnya sesuai dengan semestinya. Sebagian besar responden menjawab salah tentang: (a) sistem reproduksi, proses reproduksi, fungsi alat reproduksi, (b) pengertian bubungan seksual, (c) aktivitas seksual, (d) dampak dari melakukan hubungan seksual pra nikah, (e) pengertian aborsi, ( $f$ ) jenis penyakit yang timbul, (g) akibat hubungan seksual pra nikah, (g) dampak buruk hubungan seksual pranikah, dan (h) manfaat mengikuti seminar atau pelatihan tentang remaja dan kesehatan reproduksi.

Berdasarkan hasil uji bivariat ada hubungan pengetahuan dengan perilaku seksual pra nikah $p<0,05$ dan secara multivariat pengetahuan remaja berhubungan positif dan 


\begin{tabular}{l|c|c}
\hline JURNALPENELITIAN KESMASY & VOL. 1 NO. 2 & $\begin{array}{c}\text { EDITION: NOVEMBER 2018 - } \\
\text { APRIL2019 }\end{array}$ \\
\hline & http://ejournal.delihusada.ac.id/index.php/JPKSY & \\
\cline { 2 - 3 } RECEIVED: 6 JANUARI 2019 & REVISED: 8 MARET 2019 & ACCEPTED: 15 MARET 2019 \\
\hline
\end{tabular}

signifikan dengan perilaku seksual pra nikah. Hal ini berarti responden yang memiliki pengetahuan tidak baik mempunyai peluang 11 kali risiko tinggi terhadap perilaku seksual pra nikah dibandingkan dengan responden yang memiliki pengetahuan baik.

Hasil penelitian ini sesuai dengan hasil penelitian Gultom (2009) menyimpulkan bahwa ada hubungan tingkat pengetahuan dengan perilaku seksual di SMA Methodist 4 Medan. Demikian juga hasil penelitian Puspita dkk. (2012) menyimpulkan bahwa ada hubungan antara pengetahuan terhadap perilaku seks remaja siswa SMK Negeri 4 Jeneponto. Namun hasil penelitian ini berbeda dengan hasil penelitian Kurniawati (2001), menyimpulkan bahwa tidak terdapat hubungan yang bermakna antara pengetahuan kesehatan reproduksi dengan perilaku seks pra nikah.

\subsection{Hubungan Sikap dengan Perilaku Seksual Pra Nikah}

Responden menyikapi perilaku seks pra nikah cenderung ke arah permisif. Hal ini memberikan gambaran bahwa sebagian besar responden belum sepenuhnya merespon dengan baik tentang perilaku seks pra nikah.

Berdasarkan hasil uji bivariat ada hubungan sikap dengan perilaku seksual pra nikah $p<0,05$, dan secara multivariat sikap remaja berhubungan positif dan signifikan dengan perilaku seksual pra nikah $p<0,05$. Hal ini berarti responden yang memiliki sikap negatif mempunyai peluang 5 kali risiko tinggi terhadap perilaku seksual pra nikah dibandingkan dengan responden yang memiliki sikap positif.

Hasil penelitian ini sesuai dengan hasil penelitian Solha (2007), menyimpulkan bahwa sikap berhubungan signifikan dengan perilaku seksual. Siswa yang mempunyai sikap negatif terhadap kesehatan reproduksi mempunyai kecenderungan 1,8 kali untuk berperilaku seksual berisiko. Hal yang sama juga ditemukan dalam hasil penelitian Irmawaty (2013) menyimpulkan bahwa faktor predisposisi memiliki pengaruh yang signifikan terhadap perilaku seksual pranikah siswa, yaitu sikap dan memiliki kekuatan sebesar 15\% terhadap perilaku seksual pra nikah siswa di STIKes Medistra Indonesia Jakarta.

\subsection{HubunganSosial Ekonomi dengan Perilaku Seksual Pra Nikah}

Dilihat dari jumlah responden yang memiliki sosial ekonomi rendah,ada peluang 6 kali risiko tinggi terhadap perilaku seksual pra nikah dibandingkan dengan responden yang memiliki sosial ekonomi tinggi.

Hasil penelitian ini sejalan dengan hasil penelitian Anjarwati (2009) menyimpulkan bahwa status sosial ekonomi berhubungan secara signifikan dengan perilaku seksual remaja. Prevalensi remaja dengan status sosial ekonomi rendah memiliki perilaku seksual yang lebih tinggi dibandingkan dengan remaja yang berstatus sosial ekonomi yang lebih tinggi. Remaja dengan status sosial ekonomi rendah berpeluang 2 kali melakukan penyimpangan perilaku seksual pra nikah $(\mathrm{RP}=1,5 ; \mathrm{CI}$ $95 \%=1,15-2,05)$. Hasil penelitian ini didukung pendapat Bachtiar (2004) yang mengungkapkan bahwa dengan status perekonomian keluarga yang rendah cenderung remaja melakukan seks pra nikah agar pasangannya dapat memenuhi segala sesuatu yang ia butuhkan.

\subsection{Hubungan Akses Media Informasi dengan Perilaku Seksual Pra Nikah}

Dalam penelitian ini ditemukan media informasi yang paling banyak digunakan responden terkait dengan perilaku seksual adalah internet dan VCD. Hal ini berarti responden yang terpapar akses media informasi mempunyai peluang 5 kali beresiko terhadap perilaku seksual pra nikah bila dibandingkan dengan responden yang tidak terpapar akses media informasi dan resikonya dapat meningkat sebesar 8,63 kali jika sering mengakses media informasi yang mengandung konten pornografi (Suharsa,2007).

Kesimpulan ini senada dengan hasil penelitian Musthofa dan Winarti (2010) yang menyimpulkan bahwa akses media pornografi mempengaruhi perilaku seks pra nikah berisiko 


\begin{tabular}{l|c|c}
\hline JURNALPENELITIAN KESMASY & VOL. 1 NO. 2 & $\begin{array}{c}\text { EDITION: NOVEMBER 2018 - } \\
\text { APRIL2019 }\end{array}$ \\
\hline & http://ejournal.delihusada.ac.id/index.php/JPKSY & \\
\cline { 2 - 3 } RECEIVED: 6 JANUARI 2019 & REVISED: 8 MARET 2019 & ACCEPTED: 15 MARET 2019 \\
\hline
\end{tabular}

pada mahasiswa di Kota Pekalongan. Namun hasil penelitian ini berbeda dengan hasil penelitian Gultom (2011) yang menyimpulkan bahwa tidak terdapat hubungan yang bermakna antara pemanfaatan media televisi dan internet, tindakan orang tua terhadap media dengan perilaku seksual di SMA Methodist 4 Medan. Berdasarkan informasi yang diperoleh, maka disimpulkan bahwa akses informasi seperti televisi dan internet yang tidak mengandung konten pornografi tidak berpeluang dalam penyimpangan seksual pra-nikah.

\subsection{HubunganKetersediaan Fasilitas yang Mendukung Perilaku Berisiko dengan Perilaku Seksual Pra Nikah}

Sebagian besar disekitar wilayah responden tersedia fasilitas yang mendukung perilaku berisiko. Dalam penelitian ini ditemukan fasilitas yang paling banyak mendukung perilaku berisiko, yaitu adanya fasilitas mengakses internet tersedia dengan mudah; ketersediaan fasilitas laptop untuk mengakses hingga larut malam, dan ketersediaan fasilitas transportasi untuk keluar malam. Hal ini memicu responden untuk mengakses ketersediaan fasilitas mendukung perilaku berisiko tersebut dan mempunyai peluang 5 kali risiko tinggi terhadap perilaku seksual pra nikah dibandingkan dengan responden yang tidak memiliki ketersediaan fasilitas.

Hasil penelitian ini sesuai dengan hasil penelitian Brown dalam (Yee, 2007), menyimpulkan bahwa secara umum remaja yang paling banyak mendapat dorongan seksual dari ketersediaan fasilitas melalui media cenderung melakukan seks pada usia 14-16 tahun 2,2 kali lebih tinggi di banding dengan remaja lain yang lebih sedikit melihat eksploitasi seks dari fasilitas media.

\subsection{Hubungan Peran Orang Tua dengan Perilaku Seksual Pra Nikah}

Sebagian besar responden menyatakan mereka diawasi oleh orang tua dalam bergaul dan mendapatkan penjelasan tentang kesehatan dan perkembangan tubuh sebagai remaja. Hal ini memberikan gambaran bahwa sebagian besar anak remaja masih diawasi orangtua dengan baik.Hal ini berarti responden yang memiliki orang tua berperan dalam anggota keluarga mempunyai peluang 6 kali risiko rendah terhadap perilaku seksual pra nikah dibandingkan dengan responden yang memiliki orang tua yang tidak berperan.

Hasil penelitian ini sejalan dengan hasil penelitian Gultom (2009) yang menyimpulkan bahwa ada hubungan antara tindakan orang tua dengan perilaku seksual remaja di SMA Methodist 4 Medan. Demikian juga pada hasil penelitian Musthofa dan Winarti (2010) menyimpulkan bahwa kontrol orang tua mempengaruhi perilaku seks pra nikah pada mahasiswa di Kota Pekalongan. Namun hasil penelitian ini berbeda dengan hasil penelitian Astuti (2009) menyimpulkan bahwa peran orang tua tidak berhubungan dengan perilaku seksual pra nikah.

\subsection{Hubungan Peran Teman Sebaya dengan Perilaku Seksual Pra Nikah}

Sebagian besar responden menyatakan mereka tidak terpengaruh dengan gaya teman dalam bergaul.Hal ini berarti responden yang memiliki teman sebaya tidak berperan mempunyai peluang 7 kali risiko rendah terhadap perilaku seksual pra nikah dibandingkan dengan responden yang memiliki teman sebaya yang berperan.

Hasil penelitian ini sejalan dengan hasil penelitian Dewi (2009) menyimpulkan bahwa remaja yang mendapatkan pengaruh buruk berupa mengkonsumsi konten pornografi dari temannya memiliki peluang tiga kali $(\mathrm{OR}=3.207)$ lebih besardalam melakukan perilaku seksual pranikah bila dibandingkan dengan remaja yang mendapatkan pengaruh yang baik dari temannya.

Demikian juga pada hasil penelitian Zulhaini dan Nasution (2011) menyimpulkan bahwa ada hubungan yang signifikan antara pergaulan teman sebaya terhadap perilaku seks pranikah pada siswa kelas XI di SMA Negeri 6 Binjai 


\begin{tabular}{l|c|c}
\hline JURNALPENELITIAN KESMASY & VOL. 1 NO. 2 & $\begin{array}{c}\text { EDITION: NOVEMBER 2018 - } \\
\text { APRIL2019 }\end{array}$ \\
\hline RECEIVED: 6 JANUARI 2019 & http://ejournal.delihusada.ac.id/index.php/JPKSY & ACCEPTED: 15 MARET 2019 \\
\cline { 2 - 3 } & REVISED: 8 MARET 2019 & ACC
\end{tabular}

Tahun Ajaran 2011/2012. Namun hasil penelitian ini berbeda dengan hasil penelitian Suharsa (2006) yang menyimpulkan bahwa tidak terdapat hubungan yang bermakna antara interaksi peer group dengan perilaku seksual.

\section{KESIMPULAN}

1. Pengetahuan sebanyak $64,5 \%$ kategori tidak baik, sikap sebanyak $57,3 \%$ kategori negatif, sosial ekonomi sebanyak 54,0\% kategori rendah, akses media informasi sebanyak 54,8\% kategori terpapar, ketersediaan fasilitas yang mendukung perilaku berisiko sebanyak $58,1 \%$ kategori tersedia, peran orang tua sebanyak $58,1 \%$ kategori berperan dan peran teman sebaya sebanyak 50,8\% kategori tidak berperan serta perilaku seksual pra nikah sebanyak $52,4 \%$ kategori risiko tinggi.

2. Ada hubungan signifikan faktor predisposing (pengetahuan, sikap dan sosial ekonomi), Faktor enabling (akses media informasi, ketersediaan fasilitas yang mendukung perilaku berisiko) dan faktor reinforcing (peran orang tua dan teman sebaya) dengan perilaku seksual pra nikah.

3. Faktor predisposing (pengetahuan, sikap dan sosial ekonomi), Faktor enabling (akses media informasi, ketersediaan fasilitas yang mendukung perilaku berisiko) dan faktor reinforcing (peran orang tua dan teman sebaya) berhubungan signifikan dengan perilaku seksual pra nikah.

4. Variabel yang paling dominan berhubungan dengan perilaku seksual pra nikah adalah pengetahuan dengan nilai koefisien $(B)=$ 2,515 .

\section{DAFTAR PUSTAKA}

Anjarwati, 2009.Hubungan Status SosialEkonomiDenganPerilakuSeksualRe majaPadaSiswa SMA Negeri Di KabupatenGunungKidul.Tesis. S2 IlmuKesehatanMasyarakat UGM, Yogyakarta.
Asfriyati, 2005, MasalahKehamilanPranikahpadaRemajaD itinjaudariKesehatanReproduksi, Info KesehatanMasyarakat, The Journal of Public Health, Volume IX, Nomor 1, Juni 2005,

FakultasKesehatanMasyarakatUniversitas Sumatera Utara, Medan

Astuti, J, 2009. PengaruhKarakteristikSiswa Dan

SumberInformasiTerhadapKecenderunga nMelakukanHubunganSeksualPranikahPa daSiswa SMA Negeri Di Banda Aceh.Tesis.SekolahPascasarjanaUniversit as Sumatera Utara, Medan.

Azinar,

M.

2013.

PerilakuSeksualPranikahBeresikoterhada pKehamilanTidakDiinginkan.JurnalKemas . 8(2): $143-150$

Bachtiar, A, 2004.CintaRemaja: MengungkapPoladanPerilakuCintaRemaj

a. Yogyakarta: Sarjana Yogyakarta.

BKKBN,

2010.PenyiapanKehidupanBerkeluargaBa giRemaja, Jakarta

, 2011.KajianProfilPendudukRemaja (10-24 tahun). http://bkkbn.go.id [diakses 12 Oktober 2014]

Dewi, INCT, 2009. PengaruhFaktor Personal danLingkunganTerhadapPerilakuSeksual PranikahpadaRemaja di SMA III Baturaddendan SMA Negeri I Purwokerto.Tesis. UNDIP, Semarang.

Gultom, L, 2011. PengaruhFaktorPredisposisi, PemungkindanPendorongRemajaPenggu naSitus Internet danTelevisiTerhadapPerilakuSeksual di SMA Methodist 4 Medan. Tesis, S2 IKM FKM, USU Medan.

Irmawaty,

$\mathrm{L}$, 2013. PerilakuSeksualPraNikahPadaMahasiswa. Jurnal Kesehatan Masyarakat. KEMAS 9 (1) (2013) 44-52.

Kemenkes RI, 2011. Situasi dan Analisis Penyalahgunaan Narkoba. Pusat Data 


\begin{tabular}{|c|c|c}
\hline JURNALPENELITIAN KESMASY & VOL. 1 NO. 2 & $\begin{array}{c}\text { EDITION: NOVEMBER 2018 - } \\
\text { APRIL2019 }\end{array}$ \\
\hline \multirow{2}{*}{ RECEIVED: 6 JANUARI 2019 } & http://ejournal.delihusada.ac.id/index.php/JPKSY & ACCEPTED: 15 MARET 2019 \\
\cline { 2 - 3 } & REVISED: 8 MARET 2019 & ACE
\end{tabular}

dan informasi. Departemen Kesehatan. Direktorat Jenderal Bina Kesehatan Masyarakat, Jakarta.

KPAI. 2012. Pacaran Pertama Anak Indonesia Umur 12 Tahun . [online]. http:// KPAI Pacaran Pertama Anak Indonesia Umur 12 Tahun gaya hidup Tempo.co.htm. Diakses 24 Nopember 2014.

Kurniawati, PS., 2001. Pengaruh Informasi Perilaku Seks dan Tanggapan Mahasiswa mengenai Akibat Perilaku Seks terhadap Sikap Setuju yang dihubungkan dengan Perilaku Seks Bebas bagi Mahasiswa Akademi Kesahatan di Provinsi Banten Tahun 2000. Tesis. FKM UI.Depok

Musthofa, S.B., Fuji Winarti, 2010. Faktor Yang Mempengaruhi Perilaku Seks Pranikah Mahasiswa Di Pekalongan Tahun 20092010. Jurnal Kesehatan Reproduksi Vol. 1 No 1, Desember 2010 : $33-41$.

Puspita, S.P.M, Muhammad Iksan , Rahma, 2012. Pengetahuan, Sikap, Peran Orang Tua Perilaku Seks Remaja Siswa SMK Negeri 4 Jeneponto. Fakultas Kesehatan Masyarakat, UNHAS, Makassar.

Sarwono., S.W., 2012. Psikologi Remaja. PT Raja Grafindo Persada. Jakarta.

Suharsa, H,. 2006. Perilaku seksual Remaja pada Siswa Sekolah Menengah Atas serta Faktor-faktor yang Mempengaruhi di Kabupaten Pandeglang Tahun 2006. Tesis, FKM UI. Depok

Yee, KA., 2007. Teens Talking About Sexual Health: Girl-Directed Tools to Trigger Partner Communication. International Journal of Humanities and Social Science. 1(18): 90-101.

Zulhaini, S, MasyithahNasution, 2011. PengaruhTemanSebayaTerhadapPerilaku SeksPranikahPadaSiswaKelas XI Di SMA Negeri 6 Binjai.Intelektual Vol.6 No.1 Maret 2011. http://www.kesehatan.kompasiana.com/seksol ogi/2010/12/22/80\%-gadis-tak-lagiperawan-326500.html 